\title{
The real value of equality
}

Article

Published Version

Jubb, R. (2015) The real value of equality. The Journal of Politics, 77 (3). pp. 679-691. ISSN 0022-3816 doi: https://doi.org/10.1086/681262 Available at https://centaur.reading.ac.uk/43038/

It is advisable to refer to the publisher's version if you intend to cite from the work. See Guidance on citing.

To link to this article DOI: http://dx.doi.org/10.1086/681262

Publisher: University of Chicago Press

All outputs in CentAUR are protected by Intellectual Property Rights law, including copyright law. Copyright and IPR is retained by the creators or other copyright holders. Terms and conditions for use of this material are defined in the End User Agreement.

\section{www.reading.ac.uk/centaur}

\section{CentAUR}

Central Archive at the University of Reading

Reading's research outputs online 


\section{CHICAGO JOURNALS}

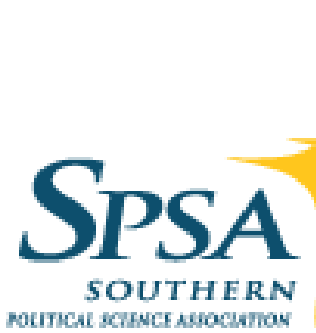

The Real Value of Equality

Author(s): Robert Jubb

Source: The Journal of Politics, Vol. 77, No. 3 (July 2015), pp. 679-691

Published by: The University of Chicago Press on behalf of the Southern Political Science

Association

Stable URL: http://www.jstor.org/stable/10.1086/681262

Accessed: 24/09/2015 05:10

Your use of the JSTOR archive indicates your acceptance of the Terms \& Conditions of Use, available at

http://www.jstor.org/page/info/about/policies/terms.jsp

JSTOR is a not-for-profit service that helps scholars, researchers, and students discover, use, and build upon a wide range of content in a trusted digital archive. We use information technology and tools to increase productivity and facilitate new forms of scholarship. For more information about JSTOR, please contact support@jstor.org. 


\section{The Real Value of Equality}

Robert Jubb, University of Leicester

This article investigates how political theorists and philosophers should understand egalitarian political demands in light of the increasingly important realist critique of much of contemporary political theory and philosophy. It suggests, first, that what Martin O'Neill has called non-intrinsic egalitarianism is, in one form at least, a potentially realistic egalitarian political project and, second, that realists may be compelled to impose an egalitarian threshold on state claims to legitimacy under certain circumstances. Non-intrinsic egalitarianism can meet realism's methodological requirements because it does not have to assume an unavailable moral consensus since it can focus on widely acknowledged bads rather than contentious claims about the good. Further, an appropriately formulated non-intrinsic egalitarianism may be a minimum requirement of an appropriately realistic claim by a political order to authoritatively structure some of its members' lives. Without at least a threshold set of egalitarian commitments, a political order seems unable to be transparent to many of its worse-off members under a plausible construal of contemporary conditions.

\section{T} his article discusses the relation between the increasingly important realist critique of much contemporary political theory and one of realism's favorite targetsa commitment to high levels of material equality as in some way central for the acceptability of a political order. I make two main claims about that relation. I argue first that what Martin O'Neill has called non-intrinsic egalitarianism is, in one form at least, a potentially realistic egalitarian political project and, second, that realists may be compelled to impose an egalitarian threshold on state claims to legitimacy under certain circumstances. Non-intrinsic egalitarianism can meet realism's methodological requirements because it does not have to assume an unavailable moral consensus since it can focus on widely acknowledged bads rather than contentious claims about the good. Further, an appropriately formulated nonintrinsic egalitarianism may be a minimum requirement of an appropriately realistic claim by a political order to authoritatively structure some of its members' lives. Without at least a threshold set of egalitarian commitments, a political order seems unable to be transparent to many of its worse-off members under a plausible construal of contemporary conditions.

Realists criticize the moralism they see as dominant in contemporary political theory for failing to understand what poli- tics is or the significance of the goods it provides. For realists, politics involves finding ways to live together despite deep and unresolvable moral disagreement, profound conflicts of interest, and an inability to consistently act morally (see, e.g., Rossi and Sleat 2014, 691). Politics is for them centrally concerned with providing a civil order that is "sine qua non for every other political good" (Galston 2010, 408). Views that assume away the problems that political institutions are supposed to solve are not in fact political at all. For example, even proponents of luck egalitarianism - the view that equality requires all and only outcomes derived from circumstance rather than choice to be equalized - recognize that luck egalitarianism lands us "up to our necks" in one of the most apparently intractable of philosophical problems, that of free will (Cohen 1989, 934). Using it as the basis of a political regime would require, at a minimum, either monolithic and unimaginably intrusive coercive state power or the kind of agreement on the metaphysics of causation that is ruled by the continued existence of politics as a sphere of human activity. In that sense, it is not a political doctrine, whatever merits it may have as an account of how, ideally, we ought to relate to each other. ${ }^{1}$

In cases like that of luck egalitarianism, realism's case seems robust. Such doctrines are simply not, in the relevant

Robert Jubb, Lecturer in Political Theory, Department of Politics and International Relations, University of Leicester, University Road, Leicester LE1 7RH, UK; robert.jubb@leicester.ac.uk.

This article was first drafted during an Early Career Fellowship from the Leverhulme Trust (ECF-2011-425).

1. There have been a number of attacks on luck egalitarianism which do not rely on the idea that it is not sufficiently political in the sense that I mean it here. The most well-known of these is probably Anderson (1999). My own discussion of that debate can be found in Jubb (2011).

The Journal of Politics, volume 77, number 3. Published online April 14, 2015. http://dx.doi.org/10.1086/681262

(C) 2015 by the Southern Political Science Association. All rights reserved. 0022-3816/2015/7703-0007\$10.00

679 
sense, political. Theories like luck egalitarianism assume levels of moral agreement among those to whom they are supposed to apply which would, independently of their application, remove the difficulties with which they are supposed to deal. Those theories' failure to answer what Bernard Williams called the "first political question" means they are, in Patrick Tomlin's terms, circular recommendations (Tomlin 2012, 43 ff.; Williams 2005a). However, that realism can successfully show that some doctrines claiming to be political philosophy are nothing of the sort does not mean we know what we should use in their place. Realists focus on the goods of civil peace, and under which circumstances and through which means it makes sense to try to achieve them. Developing a positive realist political theory then will depend on how much and what sort of civil order we need, and so steering between a crude Hobbesian insistence that might is right and the moralistic demand that political power realize the highest moral ideals, whether we can agree on what those are or not.

In this article, I explore one aspect of that question by considering the issue of how egalitarian realism can and should be. Realists have typically been resistant to the focus in contemporary political philosophy on questions of distributive justice, urging that the more properly political question of legitimacy must at least come first. ${ }^{2}$ The elaborate and highly articulated egalitarian commitments of theorists like G. A. Cohen or Ronald Dworkin are often rightly seen as exactly the sort of thing against which realists warn. Still, I will argue that certain egalitarian commitments are compatible with realism's emphasis on legitimacy and, more, may be required by it. Realists should reject egalitarianisms whose implementation depends on achieving levels of self-sacrifice or moral agreement that would radically alter the kind of political authorities to which we are subject. Demanding that we live according to a principle of community that requires us to serve others for the sake of serving them and not for our own purposes, as G. A. Cohen (2009) does, for example, is clearly ruled out. It asks for too much both in terms of motivation and of acceptance of controversial philosophical ideals to make sense as a political prescription.

However, not all egalitarianisms present in contemporary political philosophy make those sorts of demands. In order to be acceptable to realists, an egalitarianism has to make use of justificatory resources that acknowledge the ubiquity of moral disagreement and conflicts of interest in politics. It must draw on a more circumscribed set of moral and psy-

2. Enzo Rossi (2012) has even argued that moralist theories cannot apply their own prescriptions of justice without first having a theory of legitimacy . chological resources. Here, I argue that, in their standard form, egalitarianisms of the sort Martin O’Neill has called non-intrinsic are compatible with the realist emphasis on containing rather than imagining away disagreement (2008). Non-intrinsic egalitarianisms' calls for high levels of material equality are based on widely experienced and understood harms of status, and so in general this class of egalitarianism does not require moral resources on which it is unrealistic to expect political orders to be able to draw. Difficulties emerge when either the egalitarianism makes appeal to a positive moral ideal, or in circumstances where the constituencies for such egalitarianism have been marginalized, split, or attempt to satisfy their demands for self-respect in other ways. The first of these difficulties can easily be avoided though, and whether the second applies is a matter of political judgment that I am not best-placed to make. At the level of generality with which I am concerned, nonintrinsic egalitarianism is compatible with realism.

Indeed, some form of non-intrinsic egalitarianism may be required if we understand the criteria for legitimacy in the way at least one realist suggests we should around here and now. There are, at least for Bernard Williams, two ways that a political order can fail to be legitimate. As examples of what politics is supposed to replace, some political orders do not really deserve that name. They involve not the provision of civil order but "one lot of people terrorizing another lot of people" (Williams 2005a, 5). As Williams puts it, one lot of people terrorizing another lot of people is not a "political situation" but "rather, the situation which the existence of the political is in first place supposed to alleviate" (5). Slavery and the relationship between the Spartans and the Helots, Williams claims, fail to reach this standard. Yet an order may not be an example of "internalized warfare" and still fail to be legitimate (5). What Williams called the first political question may be Hobbes's, but as he notes, that does not mean that we have to take Hobbes's answer for it to be adequate (4). A political order is not legitimate simply because it is a political order and not merely a particularly successful protection racket or other form of "successful domination" (5). Avoiding treating groups of those over whom the state presumes a right to command as nothing more than recalcitrant instruments is not enough to vindicate that claim to authority. Political orders must make sense to those over whom they claim authority, and when we interpret what that implies for us in a certain way, that rules out political orders with the kinds of hierarchies against which non-intrinsic egalitarianism inveighs. Such orders do not provide those at the bottom of the hierarchies they create with an adequate return on their submission to them and so fail to be legitimate for them. Indeed, 
realists' commitment to a minimally egalitarian claim that authorities need to attempt to justify themselves to those over whom they claim authority turns out, in particular circumstances at least, to have more substantive conclusions than they might expect.

\section{NON-INTRINSIC EGALITARIANISM AS A POLITICAL DOCTRINE}

The term non-intrinsic egalitarianism was coined by Martin O'Neill to cover a range of egalitarian positions. What distinguishes non-intrinsic egalitarian positions is that their commitment to the value of distributive equality is neither weakly instrumental nor intrinsic. Rather than valuing more equal holdings of goods because such a distribution is a means to an end or because it is valuable in and of itself, non-intrinsic egalitarians value it because of a set of social relations to which it is closely connected. High levels of distributive equality are required to avoid "the badness of servility, exploitation, domination, and differences in status" $(2008,130) .^{3}$ It is a "deep social fact," O'Neill claims, that greater equality of condition will typically be both necessary and sufficient to avoid "domination and stigmatizing differences in status . . . offensive to the dignity and standing of human agents" (130). Five related kinds of harms that a collection of broadly egalitarian political theorists and moral philosophers mention as motivating their egalitarianism cluster in such a way that removing or reducing differences in income and wealth will reliably act to prevent them. ${ }^{4}$ Although of course there are other interesting issues raised by O'Neill's discussion, the question here is whether non-intrinsic egalitarianism is compatible with a realist emphasis on the unavoidability of disagreement in politics. In the remainder of this section, I suggest that realists can be non-intrinsic egalitarians as long as some presentational changes are made and some satisfactory answers to a range of mainly empirical questions about the political possibilities genuinely open to us can be found.

A non-intrinsic egalitarianism will be vulnerable to attack by realists if its justification and implementation depend on moral or psychological resources unavailable in the circumstances of politics generally or the political situation in which its particular audience find themselves. Can we reasonably expect the kinds of political orders O'Neill and

3. Like O’Neill, I ignore demands for equality associated with absolute deprivation, since equality is, after all, about your position related to that of others.

4. O'Neill (2010) discusses the relation of non-intrinsic egalitarianism to recent social epidemiology, which similarly suggests that the harms of inequality cluster and are at root related to status hierarchies. others advocate to make sense to and avoid placing too much motivational stress on agents like us, with our conflicts of interest, differing visions of the good life, and inability to consistently govern ourselves through reason alone? Clearly, agents much like us have lived and do live in societies with much higher levels of material equality than are currently experienced in, for example, the United Kingdom or the United States. The concentration of income and wealth among the richest in these societies is higher than most other similarly economically developed states and significantly higher than in a cluster of such states in Northern Europe, while there has a been a trend toward higher inequality among more or less all such states since the mid-1980s (see, e.g., OECD 2011). Unless we are to believe that Swedes were particularly saintly or oppressed in the 30 or so years after World War II, there is no reason to think that non-intrinsic egalitarianism as such fails to meet Bernard Williams's criteria of using "defensible political power" to apply "aspirations for equality and a sense of community ... to a world which is significantly driven by other sorts of motivations" $(1997,57)$. A political order that avoids domination and status hierarchies, and the servility, lack of self-respect, and mutual indifference and even hostility that go with them through high levels of material equality does not require members whose altruism is beyond that of which humans are typically capable. Equally, such an order does not have to rely on coercive police power to sustain itself but can, in spite of their differences, rest on its citizens' acceptance of the way it structures their relations. In the most general terms then, as long as O'Neill's deep social fact holds, non-intrinsic egalitarianism articulates a political demand in a way that G. A. Cohen's demand that our political communities must realize a profoundly self-sacrificing principle of community does not.

However, the details of the claims that non-intrinsic egalitarians make matter. O'Neill tends to present the view as drawing on "a complex social and political ideal of how people should best live together," which then provides an "account of the plurality of ways in which inequality can be bad" $(2008,139)$. "A complex social and political ideal of how people should best live together" will, though, because of its complexity and ambition, inevitably be subject to extensive disagreement in the circumstances of politics. Rather than a mechanism to contain disagreement to provide civil order and the accompanying peace and security, it asserts the superiority of a particular vision of the good life and bases a political order around it, ignoring its unacceptability to many of that order's members and the risk its ascendancy poses to civil order. Putting it in Rawlsian rather than conventionally realist terms, as an account of how best to live together, its comprehensiveness will make it subject to 
the burdens of judgment and mean it is not available as the basis of an overlapping consensus. Under what Rawls called "the fact of oppression," it would require "the oppressive use of state power" to serve as the basis of a political community $(2005,37)$.

Rather than O'Neill's perfectionist non-intrinsic egalitarianism, it would be better to instead emphasize the way that non-intrinsic egalitarianism links together a set of widely understood and acknowledged harms to form a case for high levels of material equality. In political terms at least, the "badness of servility, exploitation, domination, and differences in status" is not best "understood by virtue of the contrasting value of certain kinds of fraternal, egalitarian social relations" $(2008,130)$. Much as the liberalism of fear is founded on "the only certainly universal materials of politics . . . power, powerlessness, fear, cruelty," non-intrinsic egalitarianism should be seen as based on avoiding forcing people into positions of degradation that it is easy to agree are wrong or undesirable (Williams 2005b, 59). Humiliation, craven behaviour, invidious hierarchies of esteem, and the like are bad in a variety of ways. Those who suffer them tend not to like them and to be made unhappy by them. Both because of the dissatisfaction and even misery that accompanies them and because of the way they subordinate some to others and so fail to respect their agency, status inequalities can also be seen as attacks on human dignity. Even more, the experience of being treated as less than others also seems to be bad for human health in general, as the stress of being the tool of another and so having confidence in your own abilities undermined appears to have damaging effects for the cardiovascular system in particular (see Marmot 2004; O'Neill 2010). At least in political terms, the ideal is supported by the badness of what it avoids, rather than the other way round. We cannot expect enough agreement on an egalitarian ideal for it to make sense of a political order to that order's members, while it at least seems reasonable to hope that they may accept an order's explanation in terms of the harms against which it aims to protect them.

In this sense, to be acceptable to realists, non-intrinsic egalitarianism should be described as a negative ideal, with its appeal based on what it prevents. Although this is not how O'Neill presents the view, it is more faithful to the theorists whose views he is trying to reconstruct as well as appropriately political. Typically, one of the works O’Neill refers to in characterizing non-intrinsic egalitarianism is called "The Diversity of Objections to Inequality" (2008, 122 , n. 10). ${ }^{5}$ A long passage O’Neill approvingly quotes from Rawls, for example, first observes that the "effects of social

5. The reference is to Scanlon (2003). and economic inequalities" are "serious evils and the attitudes they engender great vices" and only then goes on to discuss how these problems can be remedied by a norm of equal citizenship favouring distributive mechanisms which only allow benefits when all receive them (O'Neill 2008, 126; Rawls 2001, 130-32). Similarly, Rousseau's Discourse on the Origins of Inequality, which both Rawls and O'Neill acknowledge as influential, seems better characterized as concerned with avoiding harm than realizing an ideal (O'Neill 2008, 129; Rawls 2001, 131, n. 50). The human desire for standing in the eyes of others is terrible because, left unchecked, it generates a crippling and debasing obsession with our position in various rankings that which can never satisfy any but those at their very top and continually feeds cycles of violence and domination (Rousseau [1750/1755] 1997a, 130-222). Amour-propre must be controlled not because doing so will achieve the ultimate good, but because otherwise little or nothing of any real value will exist.

This also changes the role of O'Neill's deep social fact connecting equality of status and equality of condition. Rather than forming an especially strong connection between material equality and a complex social ideal, the deep social fact now has to form such a connection between material equality and the avoidance of various widely agreed upon harms. This seems to have two benefits. First, whereas different goods tend to exclude each other, particularly the more fully they are realized, so that, for example, a life of control and moderation may not be very open to new experiences, these harms are connected and tend to cluster together. A low status leads to being dominated, which leads to being servile, which undermines confidence in judgment and capacities. Evidence presented in favour of the deep social fact is consequently more widely acceptable and less vulnerable to challenges about its relevance to the values that are expected to be achieved. The question of conflict between equality and liberty, for example, is more difficult to raise because being dominated is straightforwardly bad for both.

Second, and relatedly, there is social scientific evidence suggesting that greater material equality does connect in something like the relevant way to avoiding harms. Richard Wilkinson and Kate Pickett show high levels of correlation between a wide range of harms and income inequality in The Spirit Level, arguing that this is explained by the effect that income inequality has on status hierarchies, which then cause the poor outcomes correlated with income inequality (2009). Although they are able to correlate higher levels of trust with income equality, higher levels of trust alone do not count as realization of an egalitarian ideal. The deep social fact establishing the relation between non-intrinsic egal- 
itarianism as a negative ideal is better established than the analogous claim in non-intrinsic egalitarianism presented as a positive ideal.

Negative non-intrinsic egalitarianism has a range of advantages over positive non-intrinsic egalitarianism then, particularly in terms of its fit with realism as I understand it. It is appropriately political, not drawing on unavailable moral agreement, and has better grounded claims about the relation between particular social forms and the values it tries to achieve, as well as plausibly being a more accurate characterization of the relevant tradition. In particular, not relying on controversial claims about what is desirable about certain states of affairs or valuable in human life makes it compatible with realism's general emphasis on the importance of disagreement in understanding politics. Realism is not just about the character of politics in general though. It also emphasizes the importance of situated reasoning, which draws on the resources for containing disagreement found in particular circumstances (see, e.g., Rossi and Sleat 2014, 694). There are no political agents in the abstract, only concrete ones in particular situations, so unless non-intrinsic egalitarianism can show that it responds to the details of a real situation, it will still be faced with the question of for what and whom it is. Wilkinson and Pickett suggest that the egalitarianism they advocate can respond to worries about the disappearance of community and high levels of acquisitiveness and alienation, but there are at least three worries about whether it represents a real option here and now.

These are complex issues with which I do not have the space to deal here, and to which solutions will most probably require collaboration with scholars with other kinds of expertise. However, even if I cannot do more than gesture in the direction of answers to the following three worries, it seems worth raising them for at least two reasons. The first of these is that the identification of problems and what solutions to them might look like is one of the services one might hope that political theorists and philosophers would provide to their colleagues. The second is to be open about the limits of what I hope to have done with the arguments I have made here. It would be dishonest to pretend that I have met all the demands that realists might properly make of an egalitarian political theory simply by showing that it can deal with conflict and disagreement in the abstract. With these caveats in mind, then, let me point in the direction of what I cannot do here.

First, there is a concern about non-intrinsic egalitarianism's costs. One of the symptoms of the degrading struggle for status Rousseau found in the societies around him was an urge "to renounc[e] life in order to acquire immortality" ([1762] 1997a, 187). That desire for glory and willingness to sacrifice oneself in pursuit of it may be connected to various kinds of excellences, which we would rather not our societies were without, or which we need for our lives to be meaningful. Perhaps without damaging competition over status, we would lose a sense of the importance of some very great goods which can exclude other values from and even be destructive for individual human lives. Relatedly, the desire to distinguish oneself may also be linked to inegalitarian societies by fostering and flourishing in an environment of pluralism. It is clear that Rousseau's view that Corsica was the only European nation capable of living under a genuine social contract was in part motivated by worries about the sophistication and diversity of other European societies (1997b, 78 (2.10.6)). Relatively simple societies are more capable of containing disputes over status because there are fewer ways of differentiating oneself and so less opportunity to attempt to gain advantage by opening up a new mode of distinction. Certainly the history of egalitarian societies suggests that homogeneity and so exclusivity may be important. Declining levels of equality in Sweden partly coincide with the growth of immigration from non-Nordic countries and so increases in ethnic and cultural pluralism, for example (see, e.g., OECD 2011, fig. 1; Swedish Integration Board 2006, 19). Equally, Bernard Williams suggests that the solidarity among those who struggled for the British welfare state may have been related to their "xenophobia, brutality and sexism," that without that intolerance he claims was present in, for example, a trade union movement based around the often very male world of the industrial working class, the strong demands for material equality might have fallen away $(1997,55)$. The costs of equality may not, then, be ones that we should pay.

Second, there is the question of whether, politically and economically, high levels of material equality are possible. There are two problems here. First, there is the issue of whether, in the course of normal politics, the beneficiaries of an egalitarian politics can dominate the domestic political scene to the extent necessary to restructure the content and distribution of property rights. Even if the challenge of overcoming domestic barriers to egalitarianism can be overcome, there is then the further, if not entirely separate, worry of whether implementing egalitarian policies will not make a society uncompetitive internationally and so be economically unsustainable. Wilkinson and Pickett point to high levels of trade union membership as one of the strongest drivers of high levels of material equality, yet union membership has been declining through much of the developed world under the influence both of political assaults and the decline of the traditional heavy and nationalized industries it thrived in $(2009,245)$. They also mention the 
role of crises in creating moments of political opportunity for egalitarians, but it seems that recent crises have typically undermined, rather than strengthened, egalitarian political forces. Despite the recent success of Syrzia in Greece, at the time of writing, for example, only two of the members of the G7 have governments led by members of straightforwardly left-wing parties. One of these, the Prime Minister of Italy, Matteo Renzi, is anyway from the Christian Democrat wing of his Democratic Party, while the other, the French President Francois Hollande, is spectacularly unpopular. The increasing opening-up of domestic economies to international markets, perhaps particularly in finance, may well have significantly undermined the scope for domestic equality.

Third, non-intrinsic egalitarianism will have to make sense as a way of responding to the concerns of its beneficiaries. Wilkinson and Pickett try to argue that material equality benefits everyone, but the evidence here is unclear, even in the strongest case of poor health (see, e.g., Sreenivasan 2009), and even if it were not, the persistence of voting blocks against high levels of material equality suggests that plenty of people value dominating others more than they disvalue being dominated themselves. In the United Kingdom, support for measures to decrease material inequality is falling with the poorly off increasingly seen as feckless and responsible for their own fate (see Hills et al. 2009). Contemporary political consciousness seems to stigmatize various out-groups instead of focusing on the material inequalities which trouble non-intrinsic egalitarians. It is not obvious then that there is a political constituency for non-intrinsic egalitarianism, perhaps in part because of the political and economic changes that have made it more difficult for those intended as its constituency to collectively exercise self-determination.

It may be, of course, that an egalitarian society does not have to be boring or illiberal, that imaginative political actors are capable of gathering a dominant political coalition behind the demand to realize one, and that the economic and political environment is less hostile than often supposed to achieving that goal. Rather than trying to assess the extent to which these are realistic possibilities here and now, I merely point to a range of difficulties that non-intrinsic egalitarianism faces in our particular historical situation. My main concern in this section, after all, has been to show that at a suitably abstract and general level, non-intrinsic egalitarianism can meet realism's methodological demands. It does not have to rely on a set of justificatory resources that the mere fact of politics will necessarily deny to it as, unfortunately, many other prominent forms of contemporary philosophical egalitarianism do. Having shown that, I now want to move on to consider is the question of whether non-intrinsic egalitarianism is not only compatible with, but may be required by, realism in political theory. If nonintrinsic egalitarianism is required, then realists themselves may be compelled to take up the challenges that contemporary conditions present it or face their theory condemning itself as unrealistic given anyone who might be reasonably taken as an audience.

\section{NON-INTRINSIC EGALITARIANISM AS A LEGITIMACY CONDITION}

Realism standardly requires that a political order aims, if even it may not always succeed, at explaining itself to all those whom it purports to govern (see Hall 2013). ${ }^{6}$ It has to try to answer Hobbes's first political question of "the securing of order, protection, safety, trust, and the conditions of cooperation" in a way that makes sense for all those over whom it claims authority (Williams 2005a, 5). A political order whose answer to that question is rejected by too many of those it expects to recognize its right to rule lacks that right to rule over them. This may well leave the political order's authority over its other members fully intact, but equally, its failure to adequately explain itself to all its members may imperil the explanation it offers to some to whom it would otherwise make sense. The inability to satisfy a dissident minority seems to have been part of what brought down the former Warsaw Pact regimes, for example. Their failure was not, I think, a failure of the sort Bernard Williams claims was involved in the Spartan's rule over the Helots. That was, on Williams's account, no kind of political order at all, really. As I noted when first mentioning Williams's comments about the Spartans and the Helots, a political order is not automatically legitimate simply because it is a political order and not a particularly persistent form of extortion. There need to be other criteria, criteria of the sort that perhaps we might see the former Warsaw Pact regimes as having ceased to meet once they fell. Here I argue these criteria include avoidance of at least some of the harms that nonintrinsic egalitarianism aims at avoiding. At least under contemporary conditions, a political order that routinely subjects some of its members to the kinds of status harms on which non-intrinsic egalitarianism focuses cannot offer the objects of that disrespect a full explanation of why they ought to accept it. Or so I will claim.

It is important that my question is about social orders around here and now. Indeed, as we will see, one issue for the argument I make is how to describe and decide what counts as "around here and now." For realists, moralism's

6. Matt Sleat (2014) has suggested that it is impossible for a political order to offer a satisfactory explanation to all its members, and that this means states can never be full legitimate for realists. 
universalist ambitions are problematic, since they prevent it from addressing difficulties anyone actually faces by requiring it to ignore the particularities of the situation in or for which it is formulated. Political situations could not be entirely sui generis and still be grouped together under the same label, but they are different enough to require responses to be distinctive if they are to make sense. A structure for organizing their lives together that would be appropriate for groups living in precolonial Papua New Guinea is unlikely to seem persuasive in the United Kingdom today and vice versa. Focusing on the specifics of a given context therefore matters. That focus also avoids certain kinds of difficulties. Consider Rousseau's Second Discourse and the philosophical anthropology it provides. Amour-propre has to be a universal human characteristic which, at least when combined with certain widespread technological and social developments, necessarily generates extremely destructive competition over status. ${ }^{7}$ Such an account faces a weighty burden of proof, since it aspires to be true of all people everywhere. On the other hand, a more contextual account does not need to consider anything like the same range of evidence, even if its judgments may have to be correspondingly more fine-grained.

My case for realism needing to be comparatively strongly egalitarian around here and now depends on an argument about modernity and its character whose political importance Bernard Williams stressed throughout his career, from when he first he made it in his 1962 article, "The Idea of Equality," up until the very end of his career. The emergence of the idea that someone's "role in society is itself in some part the product of social arrangements," that it is not "somehow foreordained or inevitable that there should be these orders," alters the ways that strongly hierarchical societies can be justified (2005c, 105). After the emergence of that idea, such societies can no longer be seen as satisfactory from what Williams called the "human point of view," which is "concerned primarily with what it is for that person to live that life," rather than, say, merely the roles and titles they occupy (103). In the absence of such an idea, a strongly hierarchical society could sustain itself "without compulsion" and retain "human understanding" between the classes into which it divided its members, since that division would be unavoidable and so not a sensible focus of resentment (104). Once such a view spreads, however, markedly unequal membership becomes a deliberate frus-

7. See, e.g., Rousseau (1997a), where he says that "iron and wheat civilized men, and ruined Mankind," and native Americans did not suffer from the pathologies of corrupt amour-propre precisely because they lacked agriculture and metallurgy (168). tration of aspirations those lacking a full status could have met, had they not been denied that status. If the hierarchy is to be maintained without naked compulsion, it must be by preventing others from coming to see the necessities they have structured their lives around are nothing of the sort, and that they have been systematically deluded. This is not acceptable from the human point of view, not even to those who benefit from or favour the hierarchy. Reflecting on one's role in society and understanding it not as divinely ordered or in some other way required makes systematic inequality unacceptable, at least from a pretty minimally moral perspective.

Williams's references there to "a sentimental picture of the Middle Ages" make it clear that this "reflective consciousness" was something he thought his contemporaries certainly had but those who lived earlier perhaps did not (2005c, 105). Likewise, in Ethics and the Limits of Philos$o p h y$, for example, he says that the extent of our "urge to reflective understanding of society and our activities" makes recreating the "supposedly contented hierarchical societies of the past" impossible "since measures would have to be taken to stop people raising questions that are, by now, there to be raised" (2011, 181-82). The reference to Weber and disenchantment he makes there is repeated in Realism and Moralism in Political Theory, while an obviously similar distinctively post-Enlightenment attitude toward truth is central to the political consequences of a commitment to it in Truth and Truthfulness (Williams 2002, 231; 2005a, 9; 2011, 183). The most important of those consequences here is that "the "legitimations" of hierarchical states are perceived to be mythical" (Williams 2005a, 7), and that their justification from the human point of view requires political orders to be transparent in the way that Jeremy Waldron has argued is foundational for liberalism (1987; Williams 2005a, 9). Consequently, modern political orders must be liberal to be legitimate.

For Williams at least then, a central feature of modernity is that it has destroyed the possibility of justifications of social and political order which rest on treating that order as anything but a human construction. A major consequence of this is that the demands on explanations and justifications of those orders have increased. Raising "expectations of what a state can do" by making the social order it sustains a matter of human choice generates "more demanding standards" for an acceptable answer to the first political question $(2005 a, 7)$. Hierarchies will now be the subject of resentment, and that resentment must be addressed in terms those who have it can understand. Members of societies' hopes and ambitions may now range beyond the social and political position they happen to occupy, 
and they can sensibly demand an explanation when that position stifles or frustrates them $(2005 c, 104)$. This explanation must address them in something like their terms, since an order beyond human understanding can no longer be taken for granted and explanations that do not make sense to them can and will be rejected. The obverse of disenchantment's removal of a certain kind of explanation of hierarchy is the thinning out of the material that legitimations can draw on by increasing the range of people and perspectives to which they must be accessible. Certain hierarchies cease to be acceptable, and the barriers to justifying any political system are raised.

Obviously, there is a question about the accuracy of Williams's account, both of modernity and of its consequences. Both the temporal and the geographical boundaries of modernity have to be drawn very tightly to capture only states whose populations will not accept them unless they are liberal. Modernity will clearly not include, for example, the former Warsaw Pact states before the fall of the Berlin Wall, let alone rising powers like China. Williams's account must be more parochial than it seems to claim. ${ }^{8}$ Still, it does seem true that in the North Atlantic democratic states with which Williams was familiar, from the end of World War II and so for all his adult life, a basically liberal consensus of the sort he seems to have had in mind prevailed. Political hierarchies among citizens based on race or gender have at least usually needed a surface justification in terms that are ostensibly open to all, for example. Restricting my discussion to those North Atlantic democracies, as in effect much Anglophone political theory and philosophy anyway does, it seems reasonable to accept the set of constraints Williams sees as characterizing modernity as bearing on the discussion here. ${ }^{9}$ How egalitarian are the requirements of the demand that political orders be transparent generated by the human point of view and disenchantment?

One way of understanding the transparency requirement would be to contrast it with Rawls's liberal principle of legitimacy, another egalitarian norm of transparent political justification allegedly appropriate for modernity

8. I owe being pressed on this point to both Matt Sleat and an anonymous referee.

9. I am not sure what exactly to say about the scope of Williams's account of modernity. It may well rule out teleological ideologies like Marxism because of the way in which they can appear deterministic. That may seem an odd implication of an account of modernity. My argument here is meant to be conditional on Williams's account of modernity being accurate in at least the places I suggest it is. Whether it is a satisfactory account of modernity and what it implies about other societies is beyond the scope of my inquiry here.
(2005, xxi ff.). That principle states that "political power is fully proper only when it is exercised in accordance with a constitution the essentials of which all citizens as free and equal may reasonably be expected to endorse in light of principles and ideals acceptable to their common human reason" (137). States that do not keep to the terms the principle lays out lack authority. A realist demand for transparency will of course reject the idea that endorsement needs to be "in light of principles and ideal acceptable to common human reason," since moral and other disagreement will make that unlikely, if not impossible. A realist principle of transparency will therefore, presumably unsurprisingly, be less demanding and less moralistic than Rawls's liberal principle of legitimacy.

However, that does not mean that realists can dismiss the kinds of alienation produced by the status harms which motivate negative non-intrinsic egalitarianism as irrelevant to political legitimacy. We have already seen that drawing on the badness of humiliation and domination does not require moral or psychological resources realists take to be necessarily unavailable in political situations, as, for example it seems likely the duty of civility Rawls derives from his principle of legitimacy does $(2005,217)$. The question is not whether the harms that non-intrinsic egalitarianism tries to avoid necessarily imply elaborate moral theorizing that cannot be the basis of properly political solutions and compromises. We know they do not. The question is rather whether those harms are serious enough that their victims cannot sensibly regard their political order as having provided them with the benefits of peace and security, at least on terms they can understand and at a cost they can accept. Which kinds of harms might be serious enough to do that?

Here, the human point of view becomes central. Living a life from the inside gives us certain criteria for assessing complaints members of an order might make against it. From that perspective, the avoidable, systematic frustration or stifling of ambitions, the cramping of a life, is unacceptable. This is Williams's point about "sentimental pictures of the Middle Ages." Once the legitimations provided for their hierarchies come to seem mythological, or worse, ideological, it becomes impossible to endorse them from the human point of view since they depend, if not on brute force, on most of their members being dupes of the remainder. Sympathy for and identification with another's hopes and aspirations is not, for long at least, compatible with interactions governed by overwhelming threat advantage or conducted from behind an enchanter's cloak. A social structure that is sustained only by coercive power or mass delusion cannot claim to be concerned with the individual lives of its members since it crushes or distorts so 
many of them. Unless a political order treats its members as entitled to an opportunity for a life that is governed on their terms, then it will not be justifiable from the human point of view and so will fail to be legitimate, at least under Williams's conditions of modernity. Basic respect for individual agency is required by a realist principle of transparency because such respect is a requirement of the human point of view.

Egalitarian requirements will be included as part of a realist account of legitimacy, then, if they fall under the criteria of basic respect for individual agency. The requirements of negative non-intrinsic egalitarianism seem wellplaced here. One way of understanding the harms that egalitarianism tries to forestall and avoid is to see them as assaults on the dignity of individual agents with their own lives to lead. Domination involves one person dictating another's choices. Servility panders to an oppressor in order to soften but never loosen their grip. Both are produced by status hierarchies, which, at least when steep and ubiquitous enough, are themselves public proclamations of the insignificance and unimportance of those further down them. That the harms with which negative non-intrinsic egalitarianism is concerned are of the right type to matter for whether a political order can be endorsed from the human point of view is not enough though. To be incorporated into a realist account of legitimacy, those harms must be serious enough to systematically frustrate or constrict the ambitions of those who suffer from them. If they do so, they will close off the possibility that the system and the way it distributes its costs and benefits could make sense to the victims of those harms. Although they will acknowledge they live in a political order, they will tend to see it as an alien and exploitative force.

Measuring the gravity of harms inflicted by a social system is obviously partly an empirical matter. For example, Wilkinson and Pickett's claim that violence is correlated with levels of income inequality, serving there as a proxy for the gradient of class hierarchies, seems to suggest there is a correlation between sufficiently low status and a level of alienation such that massive breaches of the political order's ostensible structure seem appropriate $(2009,129-44)$. A willingness to commit massive breaches of the political order's ostensible structure is in turn suggestive of it having systematically frustrated or constricted ambitions in a way that gives the lie to its claim to authority. As well as that empirical evidence, though, we need a philosophical framework in which it can be placed. We cannot be sure what does and does not count as systematic frustration or constriction of ambitions without having at least a grasp on the question of why something is a frustration or constriction rather than a failure for which the agent themselves is responsible, for example.

An idea of reciprocity can, it seems, do the work here. Reciprocity requires that benefits taken are shared or repaid. Unlike reliance on naked coercion or systematic deception, features of a political order that paradigmatically cause it to fail to be acceptable to all its members, reciprocity treats others not as obstacles to be pushed or reshaped until they fit our plans but as fellow agents. When we act toward another reciprocally, we treat them as entitled to a return for the benefits we have been able to derive from them and so as having projects of their own of which we must take note. Reciprocity is characteristic of the human point of view then. It operates with the notion of a fair exchange or return that assistance or forbearance is due and so takes the sacrifices they involve seriously. Operating with such an idea of fair exchange is a kind of respect for agency since it requires that other's projects are treated with respect, not as mere instruments. Because political orders are not voluntary, they cannot rely on their members having chosen to be treated in a particular way to ground a claim to respect them as having lives of their own to lead. Instead, their treatment must be appropriate on its own terms. It must be reciprocal or, to put it negatively, not be exploitative. Hierarchies that share their benefits among their members are, in this sense at least, acceptable from the human point of view. It is, after all, precisely because the benefits of hierarchies that no longer seem foreordained appear to be directed entirely toward those at the top that those hierarchies cease to be acceptable from the human point of view.

As this observation shows, judgments of reciprocity must be relative to some kind of baseline. In the nowideological hierarchy, the baseline for judgments of reciprocity has shifted from one where receiving your due according to God's plan is a benefit to one where it is not, because God's plan no longer dictates your role. It would not make sense then to judge a set of hierarchies reciprocal simply because the more powerful do not ruthlessly exploit or oppress the weak, or because they are better off than in the absence of any political order at all. That those criteria are met simply shows that this is a political situation, that is not a situation like that of the Spartans and the Helots, and so that a political order is being provided at all. Political orders are not reciprocal and so acceptable from the human point of view simply because they are political orders. The baseline chosen has to reflect this and so cannot treat the basic goods of order that make systematic mutually beneficial interaction possible as benefits. These goods must be guaranteed. Under a broadly liberal political consciousness like ours, these presum- 
ably include the basic freedoms of person, movement, and speech and action the liberalism of fear focuses on.

The issue for the inclusion of an egalitarian threshold in realist accounts of legitimacy is what counts as a fair return over that baseline. For people like us, accepting the persistence of reasonable and irreconcilable disagreement about the sources of value in human life and that interests do not have to be malign to clash or compete, access to those benefits is enough to demonstrate a fair return. We cannot be sure which specific opportunities count as benefits, given our diversity, so tend to defer to those who are to receive them to judge whether they are a fair return on their submission to authority. Typically, it would be paternalistic of us to assume that the plan of life someone followed had resulted in the systematic frustration or constriction of their ambitions, that for them, it was empty and so no return on their acceptance of the claims of others. We would not have given proper respect to them. In this sense, our understanding of the fair return relevant to the legitimacy of political orders is relatively minimal. ${ }^{10}$

However, this realist principle of transparency has, despite its minimalism, egalitarian implications. This is because it condemns status hierarchies that are systematically reproduced across a political order, particularly when where someone is placed in the hierarchy is not the consequence of conscious choices. ${ }^{11}$ Such hierarchies are a quasi-official judgment on the worth of those within them and the lives they lead. If we systematically treat certain kinds of lives and activities as markedly superior to others, we must either ensure that they are really open to all or else accept that we publicly condemn those who cannot achieve them as inferior. This does not meet the requirement of reciprocity once what counts as a benefit over and above the bare minimum of the most basic liberties is no longer a matter on which the political order may pronounce. Those whom the hierarchies scorn are confronted by a political order that doubly wrongs them. Not only does it tell them that their lives are worth less than those that the hierarchies elevate but, in doing so, it also undermines their ability to make their lives meaningful by placing that barrier of public contempt in the way of their doing so. We cannot expect our attempts to make sense of our political order to be successful if with one

10. Exactly how minimal is not my question here, although of course it is a sensible one. Discussions over what analytically-minded liberals and liberal egalitarians tend to call neutrality are of course sophisticated and difficult. See, e.g., Gaus (2010) and Quong (2010). I hope that my basic point is robust across the various plausible views at stake in these debates.

11. In a certain sense, my argument here may be an example of the radical potential of a principle of formal equality explored by Jane Mansbridge (2005) in her "Cracking through Hegemonic Ideology: The Logic of Formal Justice." breath we insist on our agnosticism about the different lives we all lead while with the next we proclaim some worse than others, indifferent to the circumstances they are lived in. Combining neutrality and hierarchy in that way does not treat those lives it condemns as gaining a fair return for their acceptance of the political order, despite the necessity of that acquiescence for the lives in the shadow of whose superiority they must live. Once that order must be transparent to those left at the wrong end of its hierarchies, it cannot be acceptable to them. The order's attempts at justification deny that the meagre return it provides to its worst-off members is really worth having in spite of any identification they may have with it, at least in comparison to what others get. In doing so, the regime undermines their confidence and only makes it more difficult for them to achieve anything they can see as significant.

Non-intrinsic egalitarianism will be mandated then if the harms it aims to avoid are associated with nonvoluntary and encompassing hierarchies of the sort which prevent a political order from being reciprocal. In the United Kingdom at least, it seems to me that the relevant hierarchies are sufficiently general, steep, and unavoidable. Around half the difference between Britons' incomes appears to be determined by differences between their parents' income (d'Addio 2007, 32), while data on income by ethnicity and gender show that white Britons earn more than members of every other ethnic group and that typically men earn more than women for doing the same work (Perfect 2013; Platt 2011). This is to say nothing of systematic failures to respect or adequately protect the rights of disadvantaged groups, so that less than $5 \%$ of rapes result in a conviction, ${ }^{12}$ and black Britons are seven times more likely to be stopped and searched than their white fellow citizens (Ministry of Justice 2011). An order that systematically raises barriers against attempts to leave your parents' class, and which leaves women and members of ethnic minorities poorer than white men cannot, in the absence of a theological or otherwise otherworldly explanation for its continual privileging of white, middle and upper class men, reasonably claim to offer anyone else a fair return on their submission to it. ${ }^{13}$

12. The British Crime Survey suggests that 6 in 1,000 working age women in the United Kingdom were seriously sexually assaulted in 2010/ 11 (Chaplin et al. 2011, 66, table 3.02) and there are nearly 21 million such women in the United Kingdom (2011 Census, table 1), while there were less than 6,000 convictions for all sexual offences that year (Ministry of Justice 2013, 43, table Q4.1).

13. It seems unlikely that income inequalities of the sort seen in the United Kingdom are unavoidable, given that income inequality is much lower in many other developed and seemingly stable and successful states. See OECD (2011). 
Consequently, those whom the British political order disdains and discounts may reasonably refuse to acknowledge it as having a right to command them. Equally, victims of other societies' similarly steep and unavoidable hierarchies may do likewise. Giving up their authority over themselves to those orders would be a submission to an exploitative process which does not treat them as having the same sort of claims as some of its other members. They get little if anything back for what they put in, and since their return is not a matter of divine command, this can hardly be adequate. If a political order's legitimation must be transparent in Williams's sense, then that order must, if its legitimation is not to fail for many of its members, also avoid status hierarchies of the sort non-intrinsic egalitarianism condemns. Realists, round here and now, need to be pretty egalitarian - at least if Williams is right about what round here and now is like.

Indeed, evidence from the United Kingdom's last major episode of social unrest supports the idea that a certain level of equality is a requirement of realist legitimacy around here and now. A team of researchers from the LSE interviewed hundreds of those involved in the riots of the summer of 2011 which, at their peak, involved serious disturbances in 22 of London's 32 boroughs, as well as several other cities across England (Lewis et al. 2011). They found what they described as a "pervasive sense of injustice" (2011, 24). Whereas on average more than $90 \%$ of Britons describe themselves as part of British society, barely half of the alienated and marginalized interviewees did (25). The interviewees, almost two-thirds of whom were from the poorest fifth of council wards in the United Kingdom, complained about joblessness, social exclusion, changes in government policy that they felt demonstrated a lack of regard for them, and a culture of conspicuous consumption that created and then exploited desires for status they could not legally meet (2011). They also had an overwhelmingly negative view of the police. Interviewees were 8 times less likely to have a positive view of local police than Britons on average, and frequently described them as "the biggest gang out there" (18). This may be connected to $73 \%$ reporting having been stopped and searched in the last year (19). Socially excluded and marginalized rioters apparently felt that they were disregarded and mistreated by a political system, whose forces of law and order then targeted them. It is easy to understand why they would reject that system's claim to authoritatively order their social world by, for example, engaging in unrest which London's Metropolitan Police described as "unprecedented in the capital's history" (17).

Realists may not all be very happy about legitimacy requiring a certain level of socioeconomic equality around here and now. It may seem excessively moralistic to think that a political order has to constrain the levels of inequality in it so as not to do too much damage to some of its members' self-respect, to condemn stark class systems as an inadequate return on submission to authority. Yet there is conceptual or theoretical affinity between realism and egalitarian demands of this sort. In the same structural sense that G. A. Cohen's socialism is not political, realism itself is built around an egalitarian demand, a demand for a certain kind of respect. An order is only legitimate if it offers some kind of explanation of why its massively structuring, coercive power should be treated as authoritative rather than as an unfortunately extremely successful, highly sophisticated protection racket. People are entitled to reject coercion, to treat it as an affront to their dignity and those who use it as enemies, if some kind of justification they can accept cannot be given. That is itself an egalitarian commitment which, for example, refuses to demand that people sacrifice themselves for the benefit of others, which treats them as properly authoritative over themselves, as reasonable when they refuse to acquiesce in naked domination or exploitation by their supposed political authorities. Both realism and nonintrinsic egalitarianism focus on the importance of being able to govern your own life, of a life lived from the inside and not controlled by external forces. Given that, it is not entirely surprising that realism most likely will, under certain conditions, require that political orders are egalitarian or face losing their legitimacy for parts of their population.

\section{CONCLUSION}

In this article, I have argued that realism's hostility to contemporary political philosophy's tendency to see itself as a form of applied moral philosophy need to not extend to contemporary political philosophy's interest in distributive equality. First, I tried to show that realism is compatible with a certain kind of egalitarianism, that that kind of egalitarianism can be generically political, even if questions remain about whether it is appropriate in the here and now. Negative non-intrinsic egalitarianism does not require the suppression of conflicts of interest or of moral disagreement to act as a basis for a political order and so can be political in the way that realists require. I then moved on to argue that, because of a particular set of conditions political legitimations seem to have to fulfil here and now, that kind of egalitarianism may be required of political legitimations here and now, that some contemporary political orders cannot rightly claim the allegiance of all their members unless they reach some threshold of material equality. Those orders will seem exploitative to many of their members, who will rightly see the hierarchies they erect and sustain as depriving them of the chance to benefit from the 
order and so denying them a fair return on their submission to it. As such, they will not be legitimate for those members.

My discussion made it clear that both of these arguments relied on quasi-empirical claims in the direction of whose justification I have at best gestured. First, Martin O'Neill's deep social fact, connecting avoiding various status harms and humiliations with high levels of material equality, needs to hold for non-intrinsic egalitarianism to be a coherent political theory. I believe that work like that of Marmot, and Wilkinson and Pickett suggest that it does, but I am not a social psychologist or epidemiologist, and so I cannot show that it does. Second, and I assume more controversially, drawing on Bernard Williams's work, I claimed that modernity has a particular character and that this imposed certain requirements of transparency on political legitimations around here and now, at least for some values of around here and now. There, beyond an appeal to Williams's authority among realist political theorists and philosophers in particular, I can really only point to the plausibility of the conclusions he, if not I, was able to draw from those claims. I was also vague about exactly where the egalitarian threshold I drew from Williams's work ought to fall, avoiding saying more than that the United Kingdom is below it. It seems to me that these are the areas where further work needs to be done. Realism has articulated a powerful and to my mind compelling critique of the general tenor of much political philosophy. What remains is the question of with what to replace it, of what political philosophers ought to say instead, if indeed they should say anything. It is to issues like the relationship between material equality and various commonly accepted harms and the way our historical situation limits the available legitimations that our attention should now be turning then.

\section{ACKNOWLEDGMENTS}

This article was presented at the 2013 MANCEPT Workshop in Political Theory, Real Realist Legitimacy and also as part of the MANCEPT Seminar Series in 2014, and I would like to thank the audiences at both those events for their helpful and penetrating comments. I would also like to thank the two anonymous referees for their equally helpful and insightful comments, which have made the article clearer and stronger, and especially Lisa Ellis, for her judicious editorial guidance.

\section{REFERENCES}

$\rightarrow$ Anderson, Elizabeth. 1999. "What Is the Point of Equality?" Ethics 109 (2) 287-337.

Chaplin, Rupert, John Flatley, and Kevin Smith. 2011. Crime in England and Wales 2010/11. London: Home Office.

$\rightarrow$ Cohen, G. A. 1989. “On the Currency of Egalitarian Justice.” Ethics 99 (4): $906-44$.
Cohen, G. A. 2009. Why Not Socialism? Princeton, NJ: Princeton University Press.

D’Addio, Anna Cristina. 2007. Intergenerational Transmission of Disadvantage: Mobility or Immobility across Generations? A Review of the Evidence for OECD Countries. Paris: Organization for Economic Cooperation and Development.

$\rightarrow$ Galston, William. 2010. "Realism in Political Theory." European Journal of Political Theory 9 (4): 385-411.

Gaus, Gerry. 2010. The Order of Public Reason. Cambridge: Cambridge University Press.

Hall, Edward. 2013. "Bernard Williams and the Basic Legitimation Demand: A Defence." Political Studies, forthcoming. doi:10.1111/1467 -9248.12070 .

Hills, John, Tom Sefton, and Kitty Stewart. 2009. Towards a More Equal Society? Poverty, Inequality and Policy since 1997. Bristol: Policy.

$\rightarrow$ Jubb, Robert. 2011. "On the Significance of the Basic Structure: A Priori Baseline Views and Luck Egalitarianism." Critical Review of International Social and Political Philosophy 14 (1): 59-79.

Lewis, Paul, Tim Newburn, Matthew Taylor, Catriona Mcgillivray, Aster Greenhill, Harold Frayman, and Rob Proctor. 2011. Reading the Riots: Investigating England's Summer of Disorder. London: London School of Economics and Political Science and The Guardian.

$\rightarrow$ Mansbridge, Jane. 2005. "Cracking through Hegemonic Ideology: The Logic of Formal Justice.” Social Justice Research 18 (3): 335-47.

Marmot, Michael. 2004. Status Syndrome: How Your Social Standing Directly Affects Your Health. London: Bloomsbury.

Ministry of Justice. 2011. Statistics on Race and the Criminal Justice System 2010. London: Ministry of Justice.

Ministry of Justice. 2013. Criminal Justice Statistics Quarterly Update September 2012. London: Ministry of Justice.

$\rightarrow$ O’Neill, Martin. 2008. "What Should Egalitarians Believe." Philosophy and Public Affairs 36 (2): 119-56.

$\rightarrow$ O’Neill, Martin. 2010. “The Facts of Inequality.” Journal of Moral Philosophy 7 (3): 397-409.

OECD. 2011. An Overview of Growing Income Inequalities in OECD Countries: Main Findings. Paris: Organization for Economic Cooperation and Development.

Perfect, David. 2013. Gender Pay Gaps, 2012. Briefing Paper 6. London: Equality and Human Rights Commission.

Platt, Lucinda. 2011. Inequality within Ethnic Groups. York: Rowntree.

Quong, Jonathan. 2010. Liberalism without Perfection. Oxford: Oxford University Press.

Rawls, John. 2001. Justice as Fairness: A Restatement. Edited by Erin Kelly. Cambridge, MA: Harvard University Press.

Rawls, John. 2005. Political Liberalism. New York: Columbia University Press.

$\rightarrow$ Rossi, Enzo. 2012. "Justice, Legitimacy and (Normative) Authority for Political Realists." Critical Review of International Social and Political Philosophy 15 (2): 149-64.

$\rightarrow$ Rossi, Enzo, and Matt Sleat. 2014. "Realism in Normative Political Theory.” Philosophy Compass 9/10:689-701.

Rousseau, Jean-Jacques. (1750/1755) 1997a. "Discourse on the Origin and Foundations of Inequality among Men, Or Second Discourse.” In Victor Gourevitch, ed., The Discourses and Other Early Political Writings. Cambridge: Cambridge University Press, 130-222.

Rousseau, Jean-Jacques. (1762) 1997b. The Social Contract and Other Later Political Writings. Edited and translated by Victor Gourevitch, Cambridge: Cambridge University Press, 39-152.

Scanlon, T. M. 2003. “The Diversity of Objections to Inequality.” In T. M. Scanlon, ed., The Difficulty of Tolerance. Cambridge: Cambridge University Press, 202-18.

$\rightarrow$ Sleat, Matt. 2014. "Legitimacy in Realist Thought: Between Moralism and RealPolitik." Political Theory 42 (3): 314-37. 
$\rightarrow$ Sreenivasan, Gopal. 2009. "Ethics and Epidemiology: The Income Debate."Public Health Ethics 2 (1): 45-52.

Swedish Integration Board. 2006. Pocket Facts-Statistics on Integration. Stockholm: Elanders.

$\rightarrow$ Tomlin, Patrick. 2012. "Should We Be Utopophobes about Democracy in Particular.” Political Studies Review 10 (1): 36-47.

$\rightarrow$ Waldron, Jeremy. 1987. "The Theoretical Foundations of Liberalism." Philosophical Quarterly 37 (147): 127-50.

Wilkinson, Richard, and Kate Pickett. 2009. The Spirit Level. London: Allen Lane.

Williams, Bernard. 1997. "Forward to Basics." In J. Franklin, ed., Equality. London: IPPR, 49-58, 57.

Williams, Bernard. 2002. Truth and Truthfulness. Princeton, NJ: Princeton University Press.
Williams, Bernard. 2005a. "Realism and Moralism in Political Theory." In B. Williams and G. Hawthorn, eds., In the Beginning Was the Deed: Realism and Moralism in Political Argument. Princeton, NJ: Princeton University Press, 1-17.

Williams, Bernard. 2005b. "The Liberalism of Fear." In B. Williams and G. Hawthorn, eds., In the Beginning Was the Deed: Realism and Moralism in Political Argument. Princeton, NJ: Princeton University Press, 52-61.

Williams, Bernard. 2005c. "The Idea of Equality." In B. Williams and G. Hawthorn, eds., In the Beginning Was the Deed: Realism and Moralism in Political Argument. Princeton, NJ: Princeton University Press, 97-114.

Williams, Bernard. 2011. Ethics and the Limits of Philosophy. London: Routledge. 